Portland State University

PDXScholar

1975

\title{
Evaluation of the Admissions Process at Portland State University School of Social Work : Prediction and Performance
}

\author{
Paula Bates Mike \\ Portland State University \\ Nancy J. Sharff \\ Portland State University \\ Barbara Lynn Wolochow \\ Portland State University
}

Follow this and additional works at: https://pdxscholar.library.pdx.edu/open_access_etds

Part of the Social Work Commons

Let us know how access to this document benefits you.

\section{Recommended Citation}

Bates Mike, Paula; Sharff, Nancy J.; and Wolochow, Barbara Lynn, "Evaluation of the Admissions Process at Portland State University School of Social Work : Prediction and Performance" (1975). Dissertations and Theses. Paper 1809.

https://doi.org/10.15760/etd.1808

This Thesis is brought to you for free and open access. It has been accepted for inclusion in Dissertations and Theses by an authorized administrator of PDXScholar. Please contact us if we can make this document more accessible: pdxscholar@pdx.edu. 
AN ABSTRACT OF THE RESEARCH PRACTICUM OF Paula Bates Mike, Nancy J. Sharff and Barbara Lynn Wolochow for the degree of Master of Social Work, presented May 15, 1975.

TITLE: EVALUATION OF THE ADMISSIONS PROCESS AT PORTLAND STATE UNIVERSITY SCHOOL OF SOCIAL WORK; PREDICTION AND PERFORMANCE

APPROVED BY THE RESEARCH ADVISOR:

Jack C. Finley

Research Advisor

\section{ABSTRACT}

The purpose of this research practicum is to determine the predictability of an admissions rating instrument and the effectiveness of the admission process in assessing potential of individuals seeking admission to the School of Social Work, Portland State University, Fall Term, 1972. The study is based on the hypothesis that the instrument in question is an accurate predictor of student performance at the graduate level.

Research was completed through a survey of the literature and an examination of the correlation between student ratings at admission and ratings of actual performances. The method of data collection was to request class and field instructors to rate student performance on the identical instrument utilized by the school admissions panel. Parallels were then drawn to determine to what extent members of the 
admissions panel were able to pre-judge student success according to the graduate standards delineated by the instrument. 
TO THE OFFICE OF GRADUATE STUDIES AND RESEARCH:

The research advisor approves the research practicum of Paula Bates Mike, Nancy J. Sharff, and Barbara Lynn Wolochow presented May 15, 1975.

Jack C. Finley

Research Advisor

APPROVED :

Gordoh Hearn, Dean of School of Social Work

May 15, 1975 
EVALUATION OF THE ADMISSIONS PROCESS AT PORTLAND STATE UNIVERSITY SCHOOL OF SOCIAL WORK: PREDICTION AND PERFORMANCE

\author{
by \\ Paula Bates Mike \\ Nancy J. Sharff \\ Barbara Lynn Wolochow
}

A practicum submitted in partial fulfillment of the requirements for the degree of

MASTER OF SOCIAL WORK

Portland State University

1975 
TABLE OF CONTENTS

PAGE

ACKNOWLEDGEMENTS. $・$ • • • • • • • • • • • • • • CHAPTER

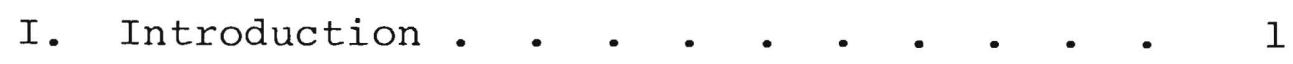

II. Historical Review of the Literature • . 4

III. Description of the Sample. • • • • • 17

IV. Methodology • • • • • • • • • . 19

Limitations of the Study . • . $\quad 22$

V. Findings • • • • • • • • • • • 24

VI. Conclusions and Recommendations. • . . 31

FOOTNOTES • • • • • • • • • • • • • • • • • 33

BIBLIOGRAPHY • • • • • • • • • • • • • • • •

APPENDIX A: ADMISSIONS WORKSHEET • • • • • • 440

APPENDIX B: MEMORANDA. • • • • • • • • • $~ 4 \quad 41$

APPENDIX C: RETURN OF WORKSHEETS • • • • • • • 45

APPENDIX D: MULTIPLE REGRESSION TABLES • • • • • 46

APPENDIX E: SUMMARY OF DISCRIMINANT FUNCTION ANALYSIS 51 


\section{ACKNOWLEDGEMENTS}

We wish to extend our appreciation to Jack C. Finley, Associate Professor and Director of Admissions, Portland State University School of Social Work, for his assistance in the design of this practicum, for facilitation of the acquisition of data, and for advice and support in completion of the project. We also wish to thank Quentin Dean Clarkson, Associate Professor, for his assistance in the statistical analysis of the data.

A special word of thanks is conveyed to Ms. Tane Hunter, secretary to the Director of Admissions, for her patience and persistence in securing essential information from student files; and to Mrs. Eralia Gonzales for typing this manuscript. 
CHAPTER I

\section{INTRODUCTION}

One of the most crucial responsibilities of schools of social work today is the competent selection of qualified applicants for graduate study. ${ }^{1}$ The question of what makes a good social worker must be repeatedly asked by admissions committees in their attempts to establish criteria for admitting students. Candidates must be selected not only for their academic performance, but also for their potential in practice. Changing times and ever growing demands on the social work profession have made it increasingly important to direct attention to the continual identification, modification and expansion of admissions criteria. The projection of professional personnel needs is, at best, filled with uncertainty; however, it is the study of current and former trends which provides us with the knowledge upon which to base future decisions of policy and recruitment programs. The need for more quantitative data on all aspects of student admission has become a recognized issue in the field of social work education. In view of these considerations, this study was undertaken specifically to examine the effectiveness of the admissions procedures used at Portland State University during the admitting year 1972 . In fall, 1971, the School of Social Work at Portland State University initiated a panel method of selecting students. Prior to that time, as in many schools throughout 
the country, the Director of Admissions assumed full responsibility for screening applicants on the basis of personal interviews and submitted material. A series of research studies carried out by the Council on Social Work Education at various schools throughout Canada and the United States suggested certain deficiencies in this method of selection regarding lack of standardization and objectivity. ${ }^{2}$ It was largely as a result of these findings that the school of Social Work revised its admissions procedures and eventually adopted the panel method of selection.

In this new method, a set of guidelines and a numerical rating system were formulated and utilized in order to evaluate applicants. Out of a total of twelve panel members, three were randomly selected to review each application. Each reviewer completed an admissions worksheet comprised of four categories: academic potential, interpersonal relations, organizations abilities and leadership and social attitudes. All four categories were assigned numerical ratings, the sum of which indicated the estimated risk in accepting that candidate.

$\begin{array}{llr}\text { Scores ranged from: } & \text { Super } & 18 \\ & \text { Low Risk } & 14-17 \\ & \text { Middle Risk } & 10-13 \\ & \text { High Risk } & 9-6 .\end{array}$

An average of the scores assigned by all three raters thus determined each candidate's suitability for graduate study. After the admissions worksheet had been in use one year, the Admissions Policy Committee and members of the 
panel began to question the effectiveness of the instrument. Concerns revolved around ill-defined categories, ambiguous phrasing, the subjectivity of the evaluation, and the degree to which this method would actually be able to predict student performance. From these issues arose the major concern of this study; specifically, whether the instrument in question can accurately measure the level at which a student will perform after admission to graduate school. 


\section{HISTORICAL REVIEW OF THE LITERATURE}

The admissions process is rarely recognized as an integral part of the school of social work's total educational responsibility. ${ }^{3}$ current, systematic, and complete information about admissions requirements has not been readily available in the past. Not only has there been a lack of clarity about the kinds of persons to be admitted, but also a fear that information about applicants is not valid or reliable. 4 Social work schools across the country have expressed the need for a quantifiable index of performance whereby certain characteristics and attributes of potential students can be measured objectively and consistently. 5

A major source of difficulty in the admissions process for social work schools is the lack of clarity about the kinds of students to be admitted. Differing expectations of social work educators and practitioners often result in conflicting criteria for selection to the masters program. Before admissions committees can attempt to establish objective criteria for admitting students to their school, they must first come to some agreement as to what a promising applicant is. Since a student's success in graduate school depends upon his performance in the field as well as in the classroom, selection must be based on much more than past academic performance. 
Although there is limited information regarding admissions policies and procedures, attempts have been made to identify characteristics of successful social work students. Between 1945 and 1950, the increased enrollment in graduate schools of social work stimulated researchers to study the process of student selection. The American Association of Schools of Social Work, the predecessor of the Council on Social Work Education, conducted a study in the fall of 1950 on the variation among schools on admissions decisions. 6 It was found that schools did tend to agree on criteria for admitting students, but there was discontinuity on the weighting given to different admission tools; applications, personal statement, letters of reference, etc. Moreover, there was common agreement concerning accepted applicants, but lack of consensus regarding those who were rejected.

As a result of the findings of the 1950 study, fiftythree graduate schools of social work in the United States and Canada met in 1963 for a National Workshop on Admissions in order to evaluate the current admissions policies. ${ }^{7}$ This conference emphasized the need to recruit social work students who could effectively seek and evaluate knowledge, were self-motivated and had a professional identity and client-oriented helping attitudes. Moreover, its review on admissions procedures precipitated a great deal of research on the development and refinement of instruments used in admissions, the improvement of decision-making processes, 
and the formulation of criteria for selection.

Though the pressing problems of recruitment and training during the early fifties took much of the emphasis away from the issue of selection, there was some research done at this time which attempted to depict background characteristics of good candidates for schools of social work. Hess and Williams described the period between the forties and fifties as a time in which there was relatively little disagreement among educators about the qualities considered desirable for graduate students of social work. "There was undoubtedly general agreement that the individual most likely to be successful required good relationship potential, high social acceptance of people, flexibility, reasonable stability, and was neither exploitive in his relationships with others nor overly dedicated and self-effacing." 8 The authors felt that in addition to possessing these personal attributes successful social work students tended to have a basically humanistic approach to life; i.e., belief in the individual, democracy, and pluralism.

In 1957 , H. W. Lundberg studied characteristics of eighty entering social work students in four midwestern universities and 180 entering students at University of Minnesota. ${ }^{9}$ He found that these students, when compared to students of other professions, tended to be more liberal in areas such as politics, economics and family ideology. Moreover, in studying the circumstances surrounding the students' 
choice of vocation, he noted that those selecting social work tended to have values which more closely parallelled those of the social work profession. ${ }^{10}$ In that same year, Anne Oren did her doctoral dissertation at the University of Minnesota on the measurement of social workers' attitudes associated with aptitudes for interpersonal relations. ${ }^{11}$ She developed a scale, the Social Worker Attitude Inventory, which proved to be highly successful in distinguishing personality factors between two contrasted experimental groups rated as superior and poor.

During the 1950's, much of the research on admissions focused on the prediction of student performance. In the fall of 1961, a large scale study of applicants was conducted by Sidney Berengarten. ${ }^{12}$ Not only was this study one of the most comprehensive, but it was also the first to deal on a national scale with the predictive nature of background information on student performance in graduate social work schools. Out of a total of sixty-four graduate schools, fifty-nine were involved in this research. 13 schools were asked to rate entering students on qualities of "intellectual endowment" and "personality equipment" on a scale indicating superior, average, marginal or risk categories. ${ }^{14}$ These same students were then evaluated in class and field work at the end of the two year program. The purpose of Berengarten's study was to test the validity of admission judgments with actual educational performance. 
In his comparison of women to men, he found that a much greater percentage of women were predicted to do better, and actually did perform at a higher level in school. Although there were no significant differences in the prediction ratings of single and married students, married students had better evaluations at the end of the two years. In contrast to the apparent expectations of faculty members, females under the age of twenty-five did better in school than the twenty-five to thirty age group. As predicted, women from ages thirty-one to forty performed at a superior level. Although women over the age of forty were not expected to be strong students, they actually did very well in the graduate program. Men from the ages of thirty-six to forty had the greatest number of superior ratings when entering school; men forty-one years and over had the poorest prognostication. In actual performance, men through the age of thirty-five could not be differentiated as either superior or poor. Overall, the rate of marginality increased with age in men. Phyllis Caroff, in her study "A Comparative Study of Applicants to Schools of Social Work 1961-62", took a subsampling of Berengarten's population in order to do a secondary analysis. She divided the population of applicants to social work schools into three groups: students who were not rejected by any school, those who were not accepted by any school, and those who were both rejected and accepted by at least one school. Her study concentrated 
on a comparison of these three groups according to background characteristics and application patterns. The "never-rejected" and the "rejected-accepted" groups were further compared on their initial ratings by faculty members when they applied to school and their final performance ratings at the end of the two year program. The data indicated that the background characteristics of the "rejected-accepted" subsample were more similar to the "never-rejected" group than the "neveraccepted" group; thus the "rejected-accepted" group was considered as part of a continuum of acceptability. Moreover, it was found that a strong positive association existed between intellectual ratings and classwork for both groups. On the other hand, personality ratings, rather than intellectual ratings, proved to be more accurate predictors of field performance, especially for the "rejected-accepted" group.

Margaret Schubert, in her research on admissions decisions at University of California at Berkeley in 1961, also dealt with the issue of forecasting student performance. 15 Whereas Berengarten had rated students according to intelligence and personality factors, schubert examined the association between admissions ratings and first year performance, on the basis of intellectual capacity, motivation and personal fitness. 16 Data from this study indicated that the rating schedule was useful to that particular school as a method of document professional judgments and arriving at decisions. Admissions ratings were positively associated 
with first year performance, but did not serve as exact predictors. Though an undergraduate major in social science could not be correlated with first year performance, the undergraduate GPA proved to be a promising measure of academic achievement in the masters program. Yet, Schubert was concerned that competent students who perform at high levels might be denied admission if selection were made solely on the basis of undergraduate GPA. The data also demonstrated that independent agreement on variables was high for both superior and poor applicants, but it was far from exact for the middle group. This led schubert to question the accuracy of this instrument in assessing borderline applicants.

A series of studies from 1962 to 1965 focused on the problem of defining criteria that would successfully predict a student's performance in social work school. John C. Kidneigh presented his paper, "Selection of Students for Schools of Social Work", to the Second National Workshop on Admissions in 1962. ${ }^{17}$ In this paper, he stresses the need to consider the objectives of the profession when selecting students for the MSW program. Moreover, he describes the admissions process as a "function of assessment and measurement whereby the instruments used to evaluate candidates must be precise enough to enhance the correctness of judgment." Ontell's study on admissions criteria at Columbia University School of Social Work in 1965 also emphasized the importance of utilizing consistent measuring devices to aid 
in the process of student selection. ${ }^{18}$ In particular, Ontell expressed a need for an instrument to objectively define qualities such as warmth, empathy, and motivation.

Dorothea Gilbert, 1963, attempted to relate background variables to actual performance in her study of University of Pennsylvania social work students. ${ }^{19}$ Although her data indicated that no single characteristic could predict whether or not a student would graduate or fail, certain factors were related to student performance. She found that it was to the student's advantage to come from a large college, have at least a $3.0 \mathrm{GPA}$, be female, white and under twenty-five years of age. Yet, in spite of these findings, Gilbert indicated that overall objective criteria have limited significance in the selection of social work students.

Olander, in 1965, developed a rating scale to predict the success of social work students at University of Southern California.20 Data indicated a statistically significant difference between accepted and rejected students when the following factors were taken into account: previous social work experience, Graduate Record Exam scores, undergraduate grades, motivation, capacity for relationships, capacity for change, professional identification, creativity and environmental opportunity.

In the past decade, the nature of admissions problems in schools of social work has changed considerably. Not only has there been an increase in applicants for the profession, 
but also a rise in demand for social services in the community. Moreover, the emergence of new and complex social problems has resulted in a change of focus for the field of social work. No longer is it a profession primarily concerned with providing therapeutically-oriented services; it also stresses appropriate intervention in the larger social arena. Thus, the expansion of the social worker's role has somewhat complicated the task of selecting persons to social work schools. Much of the literature on admissions during this period focuses on the need for experimentation and change in light of these new dimensions of social work practice.

Mary Ella Robertson, in her article "Admissions Issues and the Social Worker of the Future", 1966, suggests that the future professional social worker must be geared to positive action and assertiveness in order to contribute to problem-solving in the expanding field of social welfare.21 Moreover, she feels that admissions criteria must be continually modified to reflect new professional trends. In that same year, Solender presented his paper to the fourteenth CSWE Annual Program Meeting in New York. 22 He too emphasized the changing nature of the social work profession and the consequent need to explore attributes of students selected for graduate social work education. Solender feels that increased professional emphasis on broader societal needs calls for a flexible, creative person who can strike out in 
new directions. Moreover, he suggests that priority must be given to those candidates who are able to serve in cultural settings different from their own, who have a deep sense of social commitment, and possess the necessary communication and leadership skills.

Thomas Brigham, in his 1968 study, also cited a number of characteristics he felt to be essential attributes for social work professionals. ${ }^{23}$ His emphasis was on the need for recruits who are determined, energetic, adventuresome and self-assertive. "In these times of turbulence, when social and community action, working with groups and families, new manifestations of the alienation of youth, and racial minority group crises, needs social workers, we ought to be especially careful about the dangers of excluding the creative, the innovative, and the boatrocking." 24

In 1966, Edward Francel pointed out the need for research on the differences between individuals who are drawn to the various tracts of social work. ${ }^{25}$ Hess and Williams, in 1973, pursued this suggestion by attempting to assess personality makeup of University of Texas students oriented to clinical casework and those oriented to organizing and planning. 26 By means of a "Survey of Ethical Attitude" and an "Adjective Check List" it was found that social work students in the two social work content areas did differ in personality. Planning students were found to be more change-oriented, dominant and self-confident, but their drive for autonomy 
often resulted in manipulative and coercive action. On the other hand, clinically-oriented students tended to be anxious, self-conscious, and dissatisfied with themselves. This suggests that there are multiple factors to consider when assessing desirable characteristics of potential social work students.

Though most of the studies on admissions in the past ten years seem to be dealing with the changing role of the social work profession and the consequent need for a new kind of social work student, Stein, Linn and Furdon's study in 1974 followed up on earlier efforts to predict student performance in social work schools. ${ }^{27}$ The purpose of their research was to determine if any of the students' background characteristics were related to success in graduate school. Various tests were given in the fall of 1971 to depict open or closed mindedness, authoritarianism, alienation, and intelligence. ${ }^{28}$ Furthermore, previous academic standing and social work experience were also taken into account. At the end of the two year program, field and classroom instructors evaluated the students for overall performance on a six-point continuum from "excellent" to "very poor". It is interesting to note that classroom professors' evaluations correlated strongly with the earlier predictions, whereas field instructors' assessments were not associated with the predictor variables. The difference in ratings between faculty and field members was explained as lack of involvement of field instructors 
in the admissions process. When the researchers looked at specific demographic characteristics, they found that being married was a good predictor of classroom achievement. A possible explanation for this was that married students might be better adjusted and more motivated to succeed. Intelligence scores were found to have little predictive value and tended to favor the white, middle-class students.

In reviewing the literature on admissions policies and procedures, it is evident that there are many areas of concern in student selection. Not only must admissions committees determine who may be the most promising applicants for their graduate programs, but also who would be a good candidate for the professional field. Moreover, differing expectations of educators and practitioners have resulted in conflicting criteria for the selection of students. Though a great deal of the literature has focused on ide tifying personality attributes of successful social work stu ents, it is important to recognize the limitations of these ideal models. John Crane, in his review of the literature describing qualities of the ideal social workers, says he is "struck by the extent to which these models attempt to maximize every desirable quality." 29 Moreover, he feels that a number of these attributes are not compatible with one another. As mentioned earlier, Hess and Williams also refer to this notion in their study on differences between caseworkoriented and social planning students. They found that 
planning students, though assertive and adventuresome, often were manipulative and coercive in their attempt to achieve objectives.

Paul Deutschberger presents a rather different perspective when he warns against making double predictions about a student's potential success in the educational program and practice. ${ }^{30}$ He feels that the admissions committee has the responsibility to evaluate students only on the basis of their potential in the educational program and not according to their potential in practice. Finally, he concludes that "the admissions committee is too small and inappropriate an arena in which to bring professional education and professional practice together."31

Because the doorway into the profession is through admission to a school of social work, it is imperative that the admissions process be administered with extreme prudence and forethought. If high professional and educational standards are to be maintained, as indeed they must, then much will depend upon that resolution. The overall consensus of the literature suggests a need for continual review and refinement of admissions policies. Moreover, it remains the responsibility of the admissions committee to acquaint itself with ever emerging data regarding criteria for student selection. In view of the seriousness of these considerations, the present study has been undertaken. 
CHAPTER III

DESCRIPTION OF THE SAMPLE

A total of 408 applications for first year and five applications for second year were received at Portland state University School of Social Work for admission in fall, 1972. Prior to review by the admissions panel, 21 first year applications and one second year application were withdrawn. The admissions panel therefore examined 387 applications for first year and four applications for second year.

When the review process was completed, 112 first year applicants and four second year applicants were accepted; however, 36 first year applicants did not register, yielding a final number of 76 first year students and four second year students accepted and registered in fall, 1972. This study confined itself to examining data on 71 of the admitted first year students. Three withdrew prior to November, 1972, and two were omitted from the study for reasons of insufficient data (ratings).

Because of the School's commitment to training minorities for professional social work, a different policy was established for screening minority applicants. Most of these applicants were exempt from the regular rating procedure. Part of the rationale for this deviation from regular procedure was the need to recruit and the intent to provide additional advisory and tutorial assistance to those not meeting established criteria. By way of description, the 
first year class contained 6 Blacks, 1 Chicano, 3 American Indians, 2 Asian-Americans and 2 foreign students. In spite of the policy, some minority applicants were rated and thus were included as part of the study. Another phenomenon which occurred in this group of students was the unusually high rate of failure to complete the program. Twenty-four percent of the admitted students for first year in fall, 1972 did not receive the Master's Degree in Social Work. Reasons for failure to complete the program are not a part of this study; however, the fact that this high a percentage occurred may have some implications on the admissions process itself. 
CHAPTER IV

\section{METHODOLOGY}

The purpose of this study was to determine whether admissions ratings of admitted students were predictive of student performance in the graduate social work program at Portland State University. In order to do this, measures of actual student performance were obtained through the use of the admissions worksheet. Field instruction and methods courses were selected as appropriate areas in which performance could be assessed. A comparison of the admissions ratings and the performance ratings would provide a basis for examining the predictability of the admissions ratings. Implications could then be drawn regarding the effectiveness of the admissions process.

In spring, 1973, and fall, 1974, requests were made of all field instructors and methods professors to rate each student's performance on the admissions worksheet. The ratings were based on the assessment of the student's achievement at the end of spring quarter. Due to extenuating circumstances, the data collection could not be accomplished at the same time each year.

Memoranda were sent outlining the reasons for the study and giving explicit instructions for completion of the worksheet. $^{32}$ It was emphasized that the ratings were subjective and were to be made without consideration of such scores as 
grade point average. In spite of this distinction, some objections to completing the ratings were raised by several field instructors. Their concerns focused on the maintenance of confidentiality, the subjectivity of the ratings, and the lack of explicit definition of categories on the worksheet. The Director of Admissions clarified any confusion about directors and facilitated the acquisition of student performance ratings. A total of 86 per cent of the worksheets were returned.

In order to compensate for the subjective nature of the performance ratings, the graduate grade point average and the type of termination (completion, transfer, withdrawal) were used by the researchers as objective measures of student performance.

In addition to the four categories evaluated on the admissions worksheet, other factors were taken into consideration by the admissions panel in selecting prospective students. These consisted of: age, sex:, undergraduate grade point average, and upper division undergraduate grade point average. 33 Each of these factors was included as a variable in this study and was examined with regard to its predictive value.

The statistical operations which were applied to a total of thirteen variables were multiple regression and correlation. Five variables were selected as dependent variables: 
first year methods ratings;

second year methods ratings;

first year field placement ratings;

second year field placement ratings; and

cumulative graduate grade point average.

Each of these dependent variables was correlated with twelve independent variables. ${ }^{34}$ Any partial correlation was assessed in terms of a $t$ score and the magnitude of correlation between the dependent variable and independent variable.

Out of the total thirteen variables, eight independent variables were used in a discriminant function analysis to determine whether or not any variables were significant in the group of students who graduated versus those who did not. These independent variables were:

total second year methods ratings;

age;

total first year methods ratings;

upper division undergraduate grade point average; undergraduate grade point average;

total first year field placement ratings;

total second year field placement ratings; and sex. 


\section{LIMITATIONS OF THE STUDY}

A major factor accounting for the limitations of this research is the lack of variability in the sample. By the very nature of the admissions process, students in the school of Social Work comprise a select group. Screened according to very specific requirements, only those in the upper part of the continuum are accepted for study. This lack of diversity within the sample tends to minimize the import of the findings, thus making it difficult to draw statistically significant conclusions. Should a percentage of students with low ratings be admitted, a more accurate basis for comparison would exist.

Ill-defined criterion measures made it extremely difficult to assess background characteristics of applicants with any kind of consistency or objectivity. Not only were the categories on the worksheet ambiguous, but they were also contingent upon the evaluator's subjective impressions. Insofar as social work educators attach such crucial importance to a candidate's possession of certain personality traits, it is essential to have reliable and valid instruments to measure these characteristics.

A further limitation of this study proved to be the difficulty in obtaining complete and necessary data. Though applicants were supposed to be rated by three different panel members prior to admission, this was not always the case. Not only were some students rated by only one or two 
panel members, but some ratings were missing from the files. Moreover, minority students were, in general, exempt from the rating process. Though most of the worksheets evaluating student performance were returned, $14 \%$ were not. This may have been due to a procedural problem. At the end of the first year, field and classroom instructors were asked to rate their students during the spring. Due to circumstances beyond the control of the researchers, however, second year performance was not rated until the following fall. It is possible that the lapse of time over the summer, may have also resulted in less accurate assessments. 


\section{CHAPTER V}

\section{FINDINGS}

Data regarding student performance yielded a limited number of significant findings. Assessments of student potential at the time of admission were found to have little significance in predicting successful completion or early termination of studies. This is not surprising when one considers the slight range of variability in ratings of students actually admitted to the graduate program. High interpersonal ratings were found to be the best single predictors of successful completion. Older students with strong interpersonal skills seemed most apt to remain in the program until its conclusion. ${ }^{35}$ These findings suggest that older students may, because of more experience, possess a greater degree of such qualities as stability, perseverance, discipline and confidence, all help in meeting the demands of social work study and graduate school in general. Greater emotional maturity and often a more extensive background in the social services may better prepare older students to cope with pressures and frustrations they may encounter. It is likely, too, that older students have had more opportunities in which to increase and improve their interpersonal skills, another area where strength proves an advantage. Qualities which most favor successful completion of the program, then, do not appear to be found in younger students, less skilled in interpersonal relations. 
Examination of ratings given to students in the first year methods class showed a positive correlation with ratings attained by students in first year field work. 36 Thus, one might reasonably expect that a student sufficiently adept in handling the material in a first year methods class would be equally successful in transmitting these skills to actual practice in the social work field. Similarly, one may speculate that a student performing at a high capacity level in the field would be able to apply his practical experience to classroom work with more success than the student whose placement is causing him some difficulty. Because the first year methods course is designed primarily to equip students with basic social work skills applicable to practice in the field, it is not unlikely to find that student performance in methods and field work are, when tested, significantly related.

In further examining first year methods scores, it was found that an inverse relationship existed between these scores and the students' cumulative grade point average while in graduate school. 37 This seems to suggest that students who perform at the highest level in the first year methods course do not maintain this degree of performance in the remainder of their graduate courses. One may also derive that students who achieve general academic excellence in the school are not among the top performers in the first year methods class. One explanation for this may be that 
the brightest students academically do not find first year methods material sufficiently challenging and/or stimulating and, therefore, do not perform to their fullest capacity.

Ratings achieved by students in second year methods classes suggest that, as in first year, classroom performance is positively associated with high field performance. 38 Again one may assume that due to the close nature of the relationship between the dependent and the independent variable, students inclined to do well in second year methods work would be equally motivated and equipped to perform successfully in the field placements of their choice.

When data on field work were analyzed, a significant relationship was discerned between performance in first and in second year. 39 It would seem likely, then, that students who demonstrate superior interests and skills during their first year placements are able to maintain these capacities throughout their second year, while the performance of lower rated students does not appear to accelerate.

Although the overall predictive value of the instrument used by the admissions panel tended to be relatively low, certain correlations did exist with regard to field performance. Specifically, those whose admissions ratings showed a high score in interpersonal relations and organizational and leadership abilities, also attained a high score in first year field work. 40

Scores for each student's interpersonal rating were 
reached by attempting to assess, at the time of application, his directness, sincerity, ability to listen, integrity, sensitivity, candidness, self-confidence, and respect for himself and others.41 It appears then, according to the data in this analysis, that these characteristics are accurate indicators of the qualities necessary for successful performance in first year field work. Phyllis Caroff, in a nationwide study, also found evidence that personality ratings, rather than intellectual ratings, were most relevant in predicting student field performance. 42 Unlike the study at hand, however, Caroff did not differentiate between achievement in first and second year.

The assessment of organizational and leadership qualifications was based on the student's ability to act in a self-sufficient manner, to assume responsibility, and to manage in complex situations. In addition, personal attributes such as aggressiveness, degree of realism and idealism, initiative, adventurousness', persistency, dependability, and decisiveness were considered. 43 According to the results of this study, these qualities proved able measures of high achievement ratings in first year field work. That these characteristics are indeed crucial to the successful social work professional is corroborated by Thomas Brigham, who stresses the need to attract energetic, determined, adventuresome, innovative, and self-assertive individuals to the field. 44 Like Brigham, Sanford Solender emphasizes 
the importance of communication and leadership skills when assessing the attributes of potential social work students, for it is individuals with these qualities who are capable of making the most valued contributions in the field. 45 Interestingly enough, it was found that ratings of students' organizational abilities and interpersonal relations were not adequate measures of success in second year field work; rather data indicated that a high academic rating was significantly more predictive. 46 Moreover, academic potential was the only category on the admissions worksheet which appeared to have any significant relationship at all to second year student performance.

Scores for rating academic potential were based on past grade point average, an autobiographical statement by the student, and each applicant's cognitive style based on open-mindedness, intellectual curiosity, and observational ability. 47 The relationship between academic ratings at admission and field work performance, while supported in this study, is not corroborated by the evidence of previously documented research. Phyllis Caroff48 in her study found intellectual ratings to be non-predictive of student field peŕformance, as did stein, Linn and Furdon 49 in their study five years later. The latter study indicates specifically that such variables as previous academic standing, intelligence, open-mindedness, and other pre-determined related background characteristics have no apparent association with 
assessments by instructors of actual student performance in the field.

The variation between the present findings and those of earlier researchers is difficult to account for. One explanation for the significance of academic potential on second year field work in this study, may revolve around the differences between first and second year field programs at Portland State University. Because first year placements are generally broader in scope and less structured than those in second year, it is possible that students whose strengths lie in organizational areas are able to perform more efficiently. The increased demans of the secone year experience are accompanied by a tighter structure, more rigidly defined roles, and more exacting skills and requirements in the field. Students are ostensibly by now pursuing their own individual interests and may well be called upon to demonstrate more rigorous academic and intellectual capacities than they were in the previous year. If this is so, it follows that a high academic potential rating would be most indicative of success in second year field work as opposed to ratings of high social commitment, interpersonal or organizational skills.

A further noticeable difference between the finding of this study and those of Caroff (1969) and stein, et al (1974) lies in the area of prediction of classroom performance. While the present study reveals no significant 
relationship between any category in the admissions ratings worksheet and performance in first or second year methods classes, the earlier studies showed a strong correlation between academic potential rating and classroom instructors' evaluations. This distinction is not easily accounted for. The specific variables chosen to assess student academic performance at Portland State University were, perhaps, not as relevant to classroom performance as the variables associated with the other studies. Then, too, it is possible that the methods courses do not rely as heavily on academic strength as do the other social work courses which were considered when assessing students' classroom performance in earlier studies. Finally, it may be that ratings assigned by panel members and methods instructors were inconsistent or inaccurate, due perhaps to the ambiguous phrasing of the admissions worksheet and the subjective nature of the rating task. 


\section{CONCLUSIONS AND RECOMMENDATIONS}

In view of the lack of significant correlations, data were interpreted in terms of trends and tendencies. The researchers found that during the year in question, ratings given to students at the time of admission tended not to predict subsequent ratings of academic and field performance. When dropouts were compared with graduates, it was found that older students with high scores in interpersonal relations were more likely to complete their course of studies. Two categories on the admissions worksheet tended to predict high performance in first year field work, namely interpersonal relations and organizational and leadership abilities. Similarly, a high academic rating at the time of admission tended to predict a high rating in second year field work.

It is thus concluded that the admissions worksheet is not useful as a predictor of student performance. This conclusion supports the decision made by the admissions committee in 1974 to discontinue use of this instrument as a means of selecting candidates for graduate study. In view of the above, the need for further revision and refinement of present tools for student selection becomes increasingly apparent.

Further research efforts must address themselves to 
three distinct issues: the choice of characteristics desirable in a graduate student of social work; the problem of measuring and assessing the relative strength or weakness of the selected characteristics; and the degree to which these characteristics predict success.

Admitting a certain number of marginal applicants may compensate for the lack of variability in the sample. A comparison of the performance of these students with those given high ratings at admission would undoubtedly provide researchers and educators with a better indication of factors predicting success in graduate school.

Field instructors have their own notions of those qualities conducive to effective performance in field placement. Just as criteria for field and school vary, so too are there differences within the field itself. The conflict here may be minimized if studies were undertaken to determine specific qualities most predictive of successful performance in the particular agency or field of practice. Every effort must be made by the admissions committee to avoid discriminatory assessment of applicants. Emphasis must remain on obtaining objective criteria through ongoing research.

It is recommended that a study of this nature be conducted annually to evaluate the admissions process at Portland State University School of Social Work. 


\section{FOOTNOTES}

${ }^{1}$ Sanford Solender, "Selection of Today's Students for Tomorrow's Practice," and Mary Ella Robertson, "Admissions Issues and the Social Worker of the Future," in Observations on Admission to Graduate Social Work Education (New York: Council on Social Work Education, 1967); Shayna Stein, Margaret Lihn, and James Furdon, "Predicting Social Work Student Performance,". Journal of Education for Social Work, Vol. 10, No. 3, 1974.

${ }^{2}$ Council on Social Work Education, Admissions to Graduate Schools of Social Work: Practices, Problems and Prospects (New York: Author, 1966).

${ }^{3}$ Clarice Freud, "Discussion of 'Testing as a Tool in the Admissions Process'," in Testing as a Tool in the Admissions Process (New York City: Council on Social Work Education, 1966), p. 31 .

Ibid., p. 30 .

5 Barbara Esser, "Testing as a Tool in the Admissions Process: An Overview of Research," in Testing as a Tool in the Admissions Process (New York City: Council on Social Work Education, 1966), p. 26.

${ }^{6}$ David French and William Gordon, Applications for Admissions to Schools of Social Work, Fall Term, 1950, and Variations Among Schools in Admissions Decisions (New York: American Association of Schools of Social Work, 1952).

${ }^{7}$ Council on Social Work Education, Selection of Students for Schools of Social Work (New York: Council on Social Work $\overline{\text { Education, }} 1 \overline{95} \overline{\overline{1}, \text { p. } 2}$.

${ }^{8}$ Dolph Hess and Martha Williams, "Personality Characteristics and Value Stances of Students in Two Areas of Graduate Study," Journal of Education for Social Work, Vol. 10, No. 3, 1974, p. 43 .

${ }^{9}$ H. W. Lundberg, "Some Distinctive Characteristics of Students Entering Graduate Social Work Education," (unpublished doctoral dissertation, University of Minnesota, 1957).

${ }^{10}$ Lundberg's scale consists of the following five categories: (1) social attitudes measured by the T.A.P. Social Attitudes Scale; (2) nature of students' social origins, academic interest and choice of profession; (3) intellectual capabilities, College Vocabulary Test; (4) social class: Hollingshead's Two Factor Index of Social Position; 
analysis of difference between experienced and inexperienced social work students.

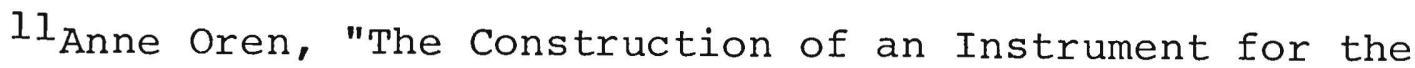
Measurement of Social Worker Attitudes Association with Aptitude for Interpersonal Relationships," (unpublished doctoral dissertation, University of Minnesota, 1957).

12 Sidney Berengarten, Admissions Prediction and student Performance in Social Work Education: An Unduplicated Count

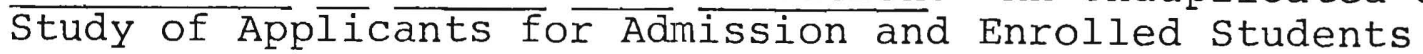
Entering Schools of Social Work, Fall Term 1961-62, (New York: Council on Social Work Education, 1964).

13 The remaining five schools did not hand in their data on time for coding.

14 "Intellectual endowment" included qualities such as intellectual capacity, judgment and discrimination, maturity of thought, imaginative capacity, and faculty of self-expression. Personality equipment included qualities such as stability, flexibility, objectivity, warmth, responsiveness, sensitivity, interpersonal relations, self-awareness and leadership.

15Margaret Schubert, "Admissions Decisions," Social Service Review, Vol. 37, No. 2, 1963.

16 Intellectual capacity was measured by past academic performance as well as the applicant's personal statement. Motivation was defined as the student's knowledge of the field, the nature of his interest, and his practical plans. Finally, personal fitness included the ability to relate to people and to tolerate stress.

17 John C. Kidneigh, "Selection of students for Schools of Social Work," The Admissions Process in Schools of Social Work (New York: Council on Social Work Education, $\overline{19} 6 \overline{2}$ ).

${ }^{18}$. Ontell, "Criteria Employed and the Reliability of Judgments in Making Decisions about the Acceptance of Applicants into the Columbia University School of Social Work," (unpublished doctoral dissertation, Columbia University, 1965).

19 Dorothea Gilbert, "Social Work Students, and their Educational Outcome" (unpublished doctoral dissertation, University of Pennsylvania, 1963).

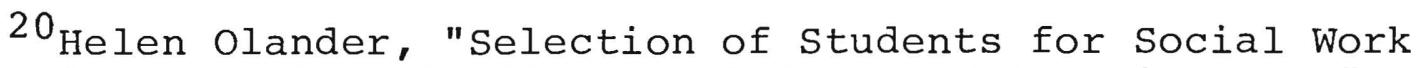
Education: Factors Predictive of Successful Achievement" (unpublished doctoral dissertation, University of Southern California, 1964). 


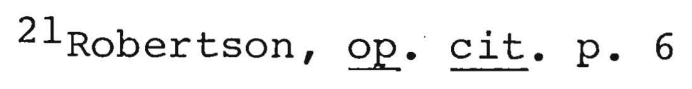

22 Solender, op. cit.

23 Thomas Brigham, "Philosophical Issues and Trends in Student Selection Today," Journal of Education for Social Work, Vol. 4, No. 2, 1968.

24 Ibid. , p. 32

25 Edward V. Francel, "The Individual: Key Factor in Welfare Manpower," Manpower and Social Welfare: Research Perspective (New York: National Association of social Workers, 1966).

$26_{\text {Hess }}$ and Williams, op. cit.

27Stein, Lihn, and Furdon, op. it.

28 Data was collected from three scales measuring attitudes and an intelligence test. In addition, demographic data was taken from students' records. The scales used for measuring attitudes were Rokeach's Dogmatism Scale, the California F Scale, and the Dean's Scale of Alienation. The Quick Test was chosen to measure intelligence.

29John Crane, Interpersonal Competence and Performance in Social Work (Vancouver, B.C.: University of British Columbia School of Social Work, 1974), p. 15.

${ }^{30}$ Paul Deutschberger, "Admissions: The Unfinished Business of Social Work Education," in Observations on Admission to Graduate Social Work Education (New York: Council on Social Work Education, 1967).

${ }^{31}$ Ibid., p. 21 .

${ }^{32}$ See Appendix B.

33Marital status was a factor available to panel members, but not utilized as a variable in this study.

${ }^{34}$ Refer to Appendix D for complete listing of variables.

35 Refer to Appendix E.

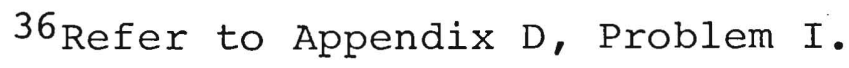

${ }^{37}$ Refer to Appendix D, Problem I.

${ }^{38}$ Refer to Appendix D, Problem II. 
${ }^{39}$ Refer to Appendix D, Problem III.

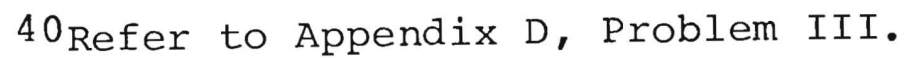

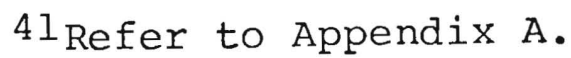

${ }^{42}$ Caroff, op. cit.

43 Refer to Appendix A.

44 Brigham, op. cit.

45 Solender, op. cit.

46 Refer to Appendix D, Problem IV.

47 Refer to Appendix A.

${ }^{48}$ Caroff, op. cit.

${ }^{49}$ Stein, Linn, and Furdon, op. cit. 


\section{BIBLIOGRAPHY}

Berengarten, S. Admissions Prediction and Student Performance in Social Work Education: An Unduplicated Count

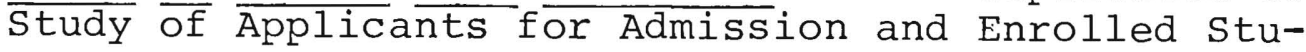
dents Entering Schools of Social Work, Fall Term 1961-62. New York: Council on Social Work Education, 1964 .

Brigham, Thomas S. "Philosophical Issues and Trends in Student Selection Today,". Journal of Education for Social Work, Vol. 4, No. 2, 1968. $27-34$

Caroff, Phyllis. "A Comparative Study of Applicants to Schools of Social Work, 1961-62, A Secondary Analysis." Columbia University School of Social Work, 1969.

Council on Social Work Education. Selection of Students for Schools of Social Work, National Workshop on Admissions 1953 and Progress in Implementation of Recommendations 1954 and 1955. New York: Author, 1955.

Council on Social Work Education. The Admissions Process in Schools of Social Work. National Admissions Workshop. New York: $\overline{\text { Author }}, \overline{1962}$.

Council on Social Work Education. Statistics on Social Work Education, November 1,1964 and Academic Year 1963-64. New York: $\overline{\text { Author, }} 1964$.

Council on Social Work Education. Statistics on Social Work Education, November 1, 1967 and Academic Year 1966-67. New York: Author, $1 \overline{9} 67$.

Crane, John A. Interpersonal Competence and Performance in Social Work. Research Project, University of British Columbia, School of Social Work, 1974.

Deutschberger, Paul. "Admissions: The Unfinished Business of Social Work Education," Observations on Admission to Graduate Social Work Education. New York: Council on Social Work Education, 1967. 16-21.

Esser, Barbara F. "Testing as a Tool in the Admissions Process: An Overview of Research," Testing as a Tool In the Admissions Process. Lebanon, New York: Council $\overline{\text { on }}$ Social Work Education, 1966.

Francel, Edward V. "The Individual: Key Factor in Welfare Manpower," Manpower and Social Welfare: Research Perspective, New York: National Association of Social Workers, 1966. 
French, D.G. and Gordon, W. E. Application for Admission To Schools of Social Work, Fall Term, 1950, and Variation Among Schools in Admissions Decisions. New York: American Association of Schools of Social Work, 1952 .

Freud, Clarice. "Discussion of 'Testing as a Tool in the Admissions Process'," in Testing as a Tool in the Admissions Process. Lebanon, New York: Council on Social Work Education, 1966.

Gilbert, Dorothea. "Social Work Students and their Educational Outcome: An Explanation of Characteristics of Students who Dropped Out and Who Graduated from the Master's Curriculum at the University of Pennsylvania School of Social Work". Unpublished Doctoral Dissertation, University of Pennsylvania, 1963.

Hanks, John. "Graduate School Admission Requirements,". Journal of Education for Social Work, Vol. 7, No. 2, 1971. $5 \overline{1-5}$.

Hess, Dolph and Williams, Martha. "Personality Characteristics and Value Stances of students in Two Areas of Graduate Study" Journal of Education for Social Work, Vol. 10, No. 3, 1974. 42-49.

Kidneigh, John C. and Lundberg, Horace W. "Are Social Work Students Different?", Social Work, Vol. 3, No. 7, 1958. 57-61.

Lundbergh, H.W. "Some Distinctive Characteristics of Students Entering Graduate Social Work Education," Social Service Review, Vol. 32, No. 3, 1958. 306.

Olander, Helen. "Selection of Students for Social Work Education: Factors Predictive of Successful Achievement.". Unpublished Doctoral Dissertation, University of Southern California, 1964 .

Ontell, R. "Criteria Employed and the Reliability of Judgments in Making Decisions about the Acceptance of Applicants into the Columbia University School of Social Work:" Unpublished Doctoral Dissertation, Columbia University, 1965.

Oren, Anne. "The Construction of an Instrument for the Measurement of Social Worker Attitudes Associated with Aptitudes for Interpersonal Relationships." Unpublished Doctoral Dissertation, University of Minnesota, 1957. 
Plumer, Stephen B. "Social Work--An Unobscured View of the Distorted Looking Glass," Observations on Admission to Graduate Social Work Education. New York: Council on Social Work Education, 1967. 22-34

Regensburg, Jeanette. "Testing the Products of Schools of Social Work," Social Work Journal, Vol. 31, No. 10, 1950. 164-70.

Robertson, Mary Ella. "Admissions Issues and the Social Worker of the Future," Observations on Admissions to Graduate Social Work Education, New York: Council on Social Work Education, 1967. 1-9.

Schubert, Margaret. "Admissions Decisions," Social Service Review, Vol. 37, No. 2, 1963. 154-65.

"Admissions Decisions: Repetition of a Study", Social Service Review, Vol. 38, No. 2, 1964. $147-152$

Solender, Sanford. "Selection of Today's Students for Tomorrow's Practice," Observations on Admission to Graduate Social Work Education. New York: Council on Social Work Education, 1967. 10-15.

Stein, Shayna; Lihn, Margaret and Furdon, James. "Predicting Social Work Student Performance," Journal of Education for Social Work, Vol. 10, No. 3, 1974. 85-90.

Towle, Charlotte. The Learner in Education for the Professions as seen in Education for Social work. Chicago, Illinois: The University of Chicago Press, 1954. 
APPENDIX A

PORTLAND STATE UNIVERSITY

School of Social Work

\section{ADMISSIONS WORKSHEET}

Applicant

Sex_Age A
Date Application Received
Cum GPA U.D. GPA_ Grad_ G_ G

INITIALS OF REVIEWER

RANGE :

SUPER (18)

Low Risk (17-14)

Middle (13-10)

High Risk (9-6)

TOTAL SCORE

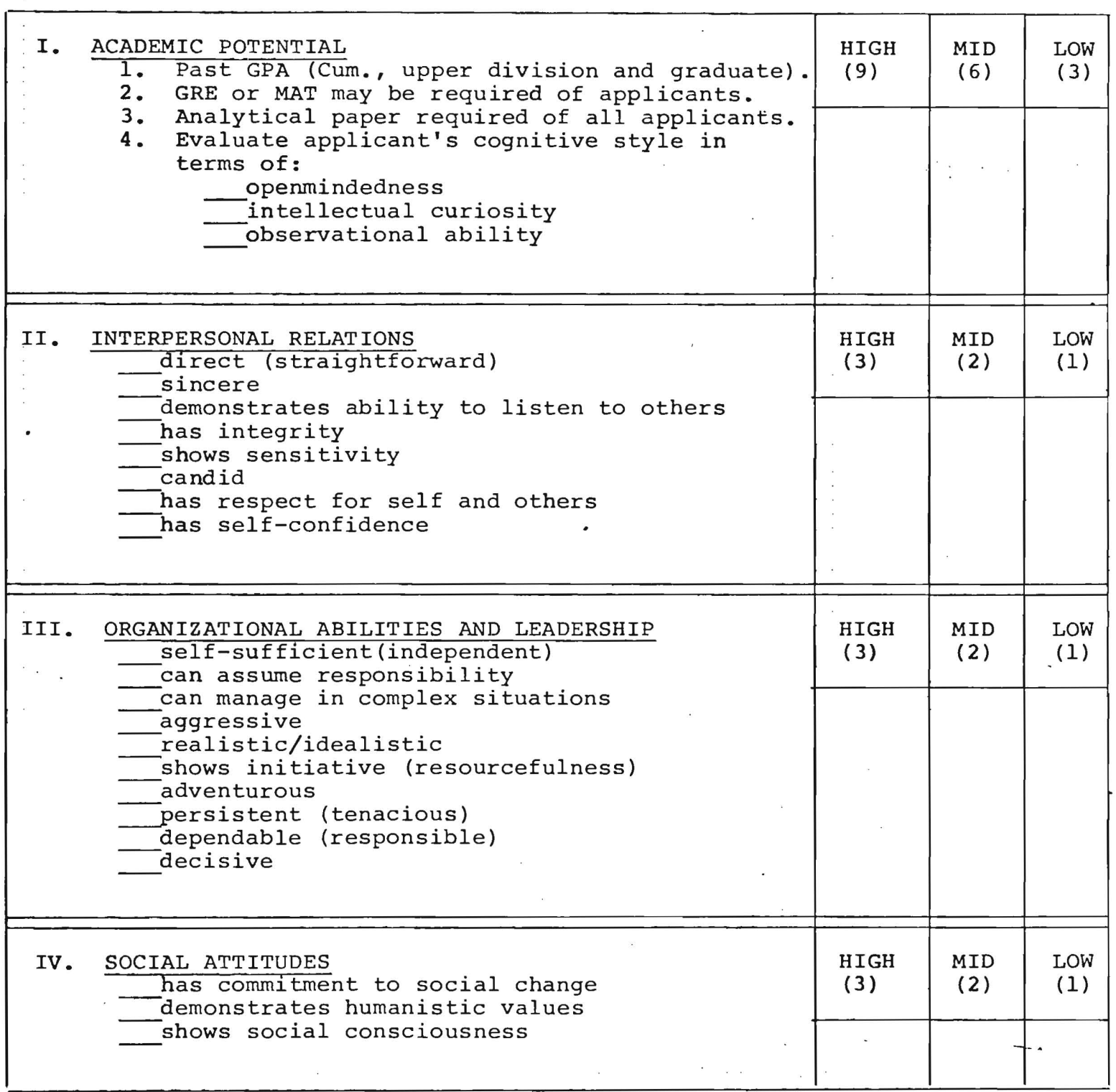


PORTLAND STATE UNIVERSITY

School of Social Work

May 21, 1973

M E M O R A N D U M

TO: Classroom and Field Instructors of First Year Students

FROM: Jack C. Finley, Director of Admissions

Paula B. Mike, student

RE: Evaluation of Admission Practices

We are requesting your assistance in providing essential data as part of a research practicum designed to evaluate the effectiveness of the current admission process.

In Fall, 1971, the School of Social Work initiated a panel method of selecting students for admission to the program. A set of guidelines and a numerical rating system were formulated and utilized in evaluation of applicants for Fall 1972 and Fall 1973. The enclosed form(s) is the same as that used by the Admissions Panel to select students.

Please fill out the form(s) regarding the student(s) indicated who has been with you in field instruction this year (whether still in placement or not) or in class spring term. Evaluation should be from your observation and not in consultation with others. The Admissions Panel uses all application material; however, we would like your subjective impression from experience with the student and without consideration of information such as GPA, GRE, MAT, etc. Ratings under category number I, Academic Potential, should be listed as 1 through 9. The remaining categories are rates as 1 through 3. The criteria listed under each category should be used as guidelines in arriving at a score but should not be considered as all inclusive. Mark a numerical score in the appropriate column (High, Medium or Low) of each of the four categories. Total the score and place this total in the appropriate space on the upper right corner of the form. If you feel unable to evaluate the student in any one of the four categories, place a question mark along side of that category.

The forms will be held in complete confidence and will not be shared with the student or other faculty. The focus of this practicum is the admissions process, not the student.

Please return to Jack Finley, School of Social Work, Portland State University, at your earliest convenience, but before 
June 8. If you have any questions, please contact Jack Finley at 229-4712. Data on each student is crucial to the study. Your assistance is vital and greatly appreciated.

$\mathrm{JCF}: \mathrm{bc}$

Enclosures 
APPENDIX B

PORTLAND STATE UNIVERSITY

School of Social Work

23 October, 1974

\section{MEMORANDUM}

To: Classroom and Field Instructors of Second Year Students $1973 / 74$

From: Jack Finley, Director of Admissions

Paula Mike, student

Nancy Sharff, student

Barbara Wolochow, student

Re: Evaluation of Admission Practices

We are requesting your assistance in providing essential data as part of a research practicum designed to evaluate the effectiveness of the admission process at the School of Social Work.

In Fall 1971, the School of Social Work initiated a panel method of selecting students for admission to the program. A set of guidelines and a numerical rating system were formulated and utilized in evaluation of applicants for Fall 1972 and Fall 1973. The enclosed form is a sample of that used by the Admissions Panel to select students.

Please fill out the form regarding the indicated student who was with you in field instruction last year (whether placement was completed or not) or in class spring term. Evaluation should be from your observation and not in consultation with others. The Admissions Panel uses all application material; however we would like your subjective impression from experience with the student and without consideration of information such as GPA, GRE, etc. Ratings under category number I, Academic Potential, should be listed as 1 through 9. The remaining categories are rated as 1 through 3. The criteria listed under each category should be used as guidelines in arriving at a score, but should not be considered as all inclusive. Mark a numerical score in the appropriate column (High, Medium or Low) of each of the four categories. Total the score and place this total in the appropriate space on the upper right corner of the form. If you feel unable to evaluate the student in any one of the four categories, place a question mark along side of that category.

The forms will be held in complete confidence and will not 
be shared with the student or other faculty. The focus of this practicum is the admission process, not the student.

Please return to Jack Finley, School of Social Work, Portland State University, at your earliest convenience, but before 15 November. If you have any questions, please contact Jack Finley at 229-4712. We realize the time and effort necessary on your part to complete this task, and we do apologize for the imposition; however data on each student is crucial to the study. Please be assured that your assistance is vital and most sincerely appreciated.

$\mathrm{JCF}: \mathrm{bw}$

Enclosures 
APPENDIX C

RETURN OF WORKSHEETS

\begin{tabular}{|c|c|c|c|}
\hline Type of Rating & $\begin{array}{l}\text { Worksheets } \\
\text { Sent }\end{array}$ & $\begin{array}{c}\text { Worksheets } \\
\text { Returned }\end{array}$ & $\%$ of Return \\
\hline First Year Methods Ratings & 59 & 53 & 89.83 \\
\hline Second Year Methods Ratings & 56 & 41 & 73.21 \\
\hline First Year Field Ratings & 67 & 60 & 89.55 \\
\hline Second Year Field Ratings & 57 & 52 & 91.23 \\
\hline TOTAL & 239 & 206 & $\bar{x}=86$ \\
\hline
\end{tabular}

$$
\begin{aligned}
& \bar{X}=\frac{\varepsilon X}{N} \\
& \bar{X}=\frac{343.820}{4} \\
& \bar{X}=85.955
\end{aligned}
$$


APPENDIX D

MULTIPLE REGRESSION

PROBLEM I

$\underline{\text { VARIABLE }}$

\section{Age}

Sex

Undergraduate GPA

Upper Division Undergraduate GPA

Second Year Methods Ratings

First Year Field Ratings

Second Year Field Ratings

Academic Potential Ratings

Interpersonal Relations Ratings

organizational Abilities and

Leadership Ratings

Social Attitudes Ratings

Graduate GPA

\section{DEPENDENT}

First Year Methods Ratinọs

Intercept

Multiple Correlation

std. Error of Estimate

\begin{tabular}{|c|c|c|c|}
\hline $\begin{array}{l}\text { STANDARD } \\
\text { DEVIATION }\end{array}$ & $\begin{array}{c}\text { CORRELATION } \\
X \text { VS Y }\end{array}$ & $\begin{array}{l}\text { REGRESSION } \\
\text { COEFFICIENT }\end{array}$ & $\begin{array}{l}\text { COMPUTED } \\
\text { T VALUE }\end{array}$ \\
\hline $\begin{array}{l}6.41062 \\
0.50253 \\
1.07493 \\
1.93368 \\
6.37118 \\
5.41214 \\
7.01682 \\
4.38787 \\
1.16612\end{array}$ & $\begin{array}{r}0.11496 \\
-0.02290 \\
0.07639 \\
-0.15704 \\
0.37704 \\
0.44099 \\
0.48179 \\
-0.03692 \\
0.25204\end{array}$ & $\begin{array}{r}0.05049 \\
0.62477 \\
0.76893 \\
-0.45780 \\
0.03610 \\
0.37487 \\
0.18023 \\
-0.16705 \\
0.70323\end{array}$ & $\begin{array}{r}0.27689 \\
0.31161 \\
0.74626 \\
-0.78962 \\
0.18745 \\
1.57362 \\
0.84218 \\
-0.66978 \\
0.83713\end{array}$ \\
\hline $\begin{array}{l}1.33687 \\
1.39179 \\
1.85618\end{array}$ & $\begin{array}{l}-0.00133 \\
-0.08112 \\
-0.42202\end{array}$ & $\begin{array}{l}-0.93935 \\
-0.27799 \\
-1.06063\end{array}$ & $\begin{array}{l}-1.12678 \\
-0.38341 \\
-1.85514\end{array}$ \\
\hline
\end{tabular}

$10.17021 \quad 6.75122$

\begin{tabular}{|c|c|c|}
\hline & & \\
\hline $\begin{array}{r}27.76596 \\
1.44680 \\
3.23212 \\
3.84212 \\
7.87234 \\
12.72340 \\
10.63829 \\
20.91489 \\
7.34042\end{array}$ & $\begin{array}{l}6.41062 \\
0.50253 \\
1.07493 \\
1.93368 \\
6.37118 \\
5.41214 \\
7.01682 \\
4.38787 \\
1.16612\end{array}$ & $\begin{array}{r}0 \\
-0\end{array}$ \\
\hline $\begin{array}{l}7.31914 \\
7.38297 \\
4.01552\end{array}$ & $\begin{array}{l}1.33687 \\
1.39179 \\
1.85618\end{array}$ & -0 \\
\hline 10.17021 & 6.75122 & \\
\hline \multicolumn{3}{|c|}{$\begin{array}{r}11.68507 \\
0.65772 \\
5.91513\end{array}$} \\
\hline
\end{tabular}

Analysis of Variance for the Regression

Source of Variation

Attributable to Regression Deviation from Regression

TOTAL

$\begin{array}{crc}\begin{array}{c}\text { Degrees of } \\ \text { Freedom }\end{array} & \begin{array}{c}\text { Sum of } \\ \text { Squares }\end{array} & \begin{array}{c}\text { Mean } \\ \text { Squares }\end{array} \\ 12 & 907.01550 & 75.58462 \\ 34 & 1189.62060 & 34.98883 \\ & & \end{array}$

F Value

2.16024 
MULTIPLE REGRESSION

PROBLEM II

\section{VARIABLE}

Age

Sex

Undergraduate GPA

Upper Division Undergraduate GPA

First Year Methods Ratings

First Year Field Ratings

Second Yeirr Field Ratings

Acad əmic Potential Ratings

Interpersonal Relations Ratings

organizational Abilities and

Leadershif Ratings

Social Attitudes Ratings

Graduate GPA

DEPENDIENT

Second Year Methods Ratings

Intercept

Multiple Correlation

Std. Error of Estimate

\begin{tabular}{|c|c|c|c|c|}
\hline MEAN & $\begin{array}{l}\text { STANDARD } \\
\text { DEVIATION }\end{array}$ & $\begin{array}{l}\text { CORRELATION } \\
\mathrm{X} \text { VS Y } \\
\end{array}$ & $\begin{array}{l}\text { REGRESS ION } \\
\text { COEFF ICIENT }\end{array}$ & $\begin{array}{l}\text { COMPUTED } \\
\text { T VALUE }\end{array}$ \\
\hline 27.76596 & 6.41062 & 0.09772 & -0.24481 & -1.55943 \\
\hline 1.44680 & $0.50 z 53$ & -0.20585 & -1.69849 & -0.96333 \\
\hline 3.23212 & $1.07: 193$ & 0.13450 & 0.45430 & 0.49312 \\
\hline 3.84212 & 1.93368 & -0.09028 & -0.15781 & -0.30346 \\
\hline 10.17021 & 6.75122 & 0.37704 & 0.02859 & 0.18745 \\
\hline 12.72340 & 5.41214 & 0.45287 & 0.01672 & 0.07617 \\
\hline 10.63829 & 7.01682 & 0.61408 & 0.55659 & 3.33055 \\
\hline 2.0 .91489 & 4.38787 & 0.14501 & -0.10595 & -0.47577 \\
\hline 7.34042 & 1.16612 & 0.19031 & 0.28105 & 0.37285 \\
\hline 7.31914 & 1.33687 & 0.24225 & 0.91201 & 1.23351 \\
\hline 7.38297 & 1.39179 & -0.08752 & -0.68372 & -1.07506 \\
\hline 4.01552 & 1.85618 & -0.34668 & -0.23978 & -0.45037 \\
\hline
\end{tabular}

7.87234

6.37118
9.32900

0.70377
5.26477

Analysis of Variance for the Regression

\section{Source of Variation}

Attributable to Regression Deviation from Regression

TOTAL

$\begin{array}{crc}\begin{array}{c}\text { Degrees of } \\ \text { Freedom }\end{array} & \begin{array}{r}\text { Sum of } \\ \text { Squares }\end{array} & \begin{array}{c}\text { Mean } \\ \text { Squares }\end{array} \\ \text { i2 } & 924.82605 & 77.06883 \\ 34 & 942.40661 & 27.71783 \\ & & \end{array}$

46

1867.23266 
MULTIPLE REGRESSION

PROBLEM III

\section{VARIABLE}

Age

Sex

Undergraduate GPA

Upper Division Undergraduate GPA

First Year Methods Ratings

Second Year Methods Ratings

Second Year Field Ratings

Academic Potential Ratings

Interpersonal Relations Ratings

Organizational Abilities and

Leadership Ratings

Social Attitudes Ratings

Graduate GPA

\section{DEPENDENT}

First Year Field Ratings

Intercept

Multiple Correlation

std. Error of Estimate
STANDARD

DEVIATION

MEAN

27.76596

1.44680

3.23212

3.84212

10.17021

7.87234

10.63829

20.91489

7.34042

7. 31914

7.38297

4.01552

6.41062
0.50253

0.50253

1.93368

6.75122

6.37118

7.01682

4.38787

1.16612

1. 33687

1.39179

1. 85618

CORRELATION

$\frac{X \text { VS Y }}{-0.08336}$

$-0.29726$

0.14520

$-0.14894$

0.44099

0.45287

0.45812

0.19946

0.35969

0.34597

0.14135

$-0.24060$

12.72340

5.41214

$-0.40572$

0.75728

4.11129

Analysis of Variance for the Regression

Source of Variation

Attributable to Regression Deviation from Regression

TOTAL

\section{Degrees of}

Sum of

Squares

12

772.70898

574.69360

46
Mean

Squares

64.39241

16.90275
REGRESSION

COEFFICIENT

$-0.30190$

$-1.65981$

0.72663

$-0.45283$

0.18109

0.01020

0.27579

0.13227

0.92332

0.97646

0.23212
0.01091
COMPUTED

$T$ VALUE

$-2.60581$

$-1.21493$

1.02175

$-1.13445$

1.57362

0.07617

1.93327

0.76456

1.62497

1.72552

0.46106

0.02617 
MULTIPLE REGRESSION

PROBLEM IV

VARIABLE

Age

Undergraduate

Upper Division Undergraduate GPA

First Year Methods Ratings

Second Year Methods Ratings

First Year Field Ratings

Academic Potential Ratings

Interpersonal Relations Ratings

Organizational Abilities and

Leadership Ratings

Social Attitudes Ratings

Graduate GPA

DEPENDENT

Second Year Field Ratings

\section{Intercept \\ Multiple Correlation \\ Standard Error of Estimate}

STANDARD

DEVIATION

CORRELATION $X$ VS $Y$

6.41062

0.50253

1.07493

1.93368

6.75122

6.37118

5.41214

1.16612

1.33687

1.39179

1.85618

0.41128

$-0.07647$

0.12720

$-0.09011$

0.48179

0.61408

0.45812

0.27858

0.17212

0.12612

$-0.10571$

$-0.40828$

4.01552

10.63829

7.01682

$-10.86846$

0.81828

4.69145

Analysis of Variance for the Regression

Source of Variation

Attributable to Regression Deviation from Regression

TOTAL

$\begin{array}{crr}\begin{array}{c}\text { Degrees of } \\ \text { Freedom }\end{array} & \begin{array}{r}\text { Sum of } \\ \text { Squares }\end{array} & \begin{array}{c}\text { Mean } \\ \text { Squares }\end{array} \\ 12 & 1516.51636 & 126.37635 \\ 34 & 748.33068 & 22.00972 \\ 46 & 2264.84717 & \end{array}$

REGRESSION COEFFICIENT

COMPUTED T VALUE

0.43130

1.79976

0.04420

$-0.17940$

0.11337

0.44196

0.35911

0.31619

$-0.20703$

$-0.96567$

0.37637

$-0.63066$

3.46451

1.15204

0.05366

$-0.38747$

0.84218

3. 33054

1.93327

1.65039

$-0.30801$

$-1.47939$

0.65724

$-1.36096$
F Value

5.74184 
MULTIPLE REGRESSION

PROBLEM V

VARIABLE

\section{Age}

Sex

Undergraduate GPA

Upper Division. Undergraduate GPA

First Year Methods Ratings

Second Year Methods Ratings

First Year Field Ratings

Second Year Field Ratings

Academic Potential Ratings

Interpersonal Relations Ratings

Organizational Abilities and

Leadership Ratings

Social Attitudes Ratings

\section{DEPENDENT}

Graduate GPA
STANDARD

DEVIATION

CORRELATION

MEAN

27.76596

7.76596

3.23212

3.84212

10.17021

7.87234

12.72340

10.63829

20.91489

7.34042

7. 31914

7.38297

6.41062

0.50253

1.07493

1.93368

6.75122

6.37118

5.41214

7.01682

7.01682

4.38787
1.16612

1. 33687

1.39179

$-0$

$-0.14271$

0.00894

0.00513

$-0.08323$

$-0.42202$

$-0.34668$

$-0.24060$

$-0.40828$

0.09918

$-0.07721$

$-0.22972$

$-0.04350$

1.85618

4.01552

5.25328

0.62184

Multiple Correlation

1.69082

std. Error of Estimate

Analysis of Variance for the Regression

\begin{abstract}
Source of Variation
\end{abstract}
Attributable to Regression

Deviation from Regression

TOTAL

$\begin{array}{crc}\begin{array}{c}\text { Degrees of } \\ \text { Freedom }\end{array} & \begin{array}{c}\text { Sum of } \\ \text { Squares }\end{array} & \begin{array}{c}\text { Mean } \\ \text { Squares }\end{array} \\ 12 & 61.28713 & 5.10726 \\ 34 & 97.20248 & 2.85889 \\ 46 & 158.48962 & \end{array}$

46
REGRESSION

0.00109

$-0.07222$

0.26713

$-0.28715$

$-0.08666$

$-0.02473$

0.00184

$-0.08191$

0.10754

0.14540

$-0.34348$

-0.34348
0.02675
COMPUTED
VALUE

0.02104

$-0.12586$

0.91055

$-1.79667$

$-1.85513$

$-0.45037$

0.02617

$-1.36097$

1.55074

0.60259

$-1.45884$

0.12882

\begin{abstract}
158.48962
\end{abstract}




\section{APPENDIX E}

\section{DISCRIMINANT FUNCTION ANALYSIS}

\section{SUMMARY TABLE}

$\begin{array}{cl}\begin{array}{c}\text { Step } \\ \text { Number }\end{array} & \text { Entered Removed } \\ 1 & \text { Total Second Year Methods } \\ 2 & \text { Age } \\ 3 & \text { Total First Year Methods } \\ 4 & \text { Upper Division Undergrad GPA } \\ 5 & \text { Undergrad GPA } \\ 6 & \text { Total First Year Field } \\ 7 & \text { Total Second Year Field } \\ 8 & \text { Sex }\end{array}$

F Value to Enter or Remove
3.7286
2.8678
1.5415
1.4984
1.5709
0.8892
0.2167
0.0291

Number of Variables Included

\section{U-Statistic}

0.9219

0.8642

0.8336

0.8042

0.7739

0.7566

0.7523

0.7517 